\title{
Restoring Less-Speech-Restrictive Alternatives After Ward $v$ Rock Against Racism
}

\author{
Jon P. Tasso $\dagger$
}

In the late 1980s, Rock Against Racism, a concert organizer, had a penchant for producing noisy concerts in New York City's Central Park. ${ }^{1}$ The City responded by promulgating a "use guideline" that required concert producers in the Park to use a sound technician employed by the City's Department of Parks and Recreation. ${ }^{2}$ Rather than allow the City to dictate its productions, however, Rock Against Racism sought to enjoin enforcement of the guideline. ${ }^{3}$ The district court upheld the City's guideline, but the Second Circuit found that the guideline violated the First Amendment. The Second Circuit concluded, among other things, that the City could have reduced concert noise through less-speech-restrictive means, such as instructing Rock Against Racism's own sound technician to keep concert noise below certain levels. ${ }^{4}$

In Ward $v$ Rock Against Racism, the Supreme Court reversed. ${ }^{5}$ The Court first determined that the guideline was a content-neutral speech regulation. ${ }^{6}$ It then reaffirmed its previously established view that content-neutral regulations, even those of public fora, do not deserve the strict judicial scrutiny afforded content-based regulations. ${ }^{7}$ The Court then charted new juris-

† B.A. 1992, M.S. 1994, Brigham Young University; J.D. Candidate 1997, The University of Chicago.

' Ward v Rock Against Racism, 491 US 781, 785 (1989).

"Id at 785-87. The guideline in question reads, in relevant part: "Department of Parks and Recreation is to be the sole and only provider of sound amplification ... [and] will employ a professional sound technician [who] will be fully versed in sound bounce patterns, daily air currents, and sound skipping." Id at 787 n 2, quoting New York City Parks Department, Use Guidelines for the Naumberg Bandshell: Sound Amplification Appendix 375-76 (1987).

"Ward, 491 US at 787.

- Id at 789.

- 491 US 781, 789-90 (1989).

" The guideline was content-neutral because its objective was to control noise levels, rather than curtail the music's message. Id at 792-93. The justification for the guidelines had "nothing to do with content." Id at 792, quoting Boos v Barry, 485 US 312, 320 (1988).

"Ward, 491 US at 797. Content-based regulations of protected speech, in contrast, are subject to strict judicial scrutiny. In the speech category of advocacy of unlawful conduct, for example, the Supreme Court has adhered rigidly to its formulation of the clear 
prudential territory by juxtaposing two seemingly contradictory ideas. First, the Court explained that content-neutral speech regulations will be upheld if they merely advance a "substantial government interest" speech than is necessary." The Court then stated, however, that reviewing courts are not to assess the existence of less-speechrestrictive alternatives to content-neutral regulations. ${ }^{10}$

Circuit courts have struggled to reconcile these two ideas. The seeming contradiction is simply put: How can a court assess whether a regulation restricts "substantially more speech than is necessary"11 without considering the existence of less-speechrestrictive alternatives? The prevailing view among the circuits resolves this apparent contradiction in favor of government actors. In these courts, if the government can show that its contentneutral speech restriction advances a government interest, the restriction is usually upheld. ${ }^{12}$ Since Ward, these courts have avoided discussing the possibility that a content-neutral speech regulation restricted too much speech. The D.C. Circuit, however, has developed an alternative understanding of Ward that recognizes the contradiction and resolves it in a different way. Under this approach, the breadth of a content-neutral speech regulation can justify a judicial analysis of less-speech-restrictive alternatives. ${ }^{13}$

As interest in using America's parks, streets, and sidewalks for expressive purposes has increased, ${ }^{14}$ so has the need for a judicial doctrine undèr which content-neutral and content-based regulations are recognized as equally capable of limiting speech..$^{15}$

and present danger standard in Brandenburg $v$ Ohio, 395 US 444, 447-49 (1969). See Hess $v$ Indiana, 414 US 105, 108 (1973); NAACP v Claiborne Hardware Co, 458 US 886, 927-28 (1982).

${ }^{8}$ Ward, 491 US at 799, quoting United States v Albertini, 472 US 675, 689 (1985).

9 Ward, 491 US at 799 .

${ }^{10}$ Id at 800 .

"Id at 799 (emphasis added).

${ }_{12}$ See, for example, Association of Community Organizations for Reform Now $v$ St. Louis County, 930 F2d 591, 595-96 (8th Cir 1991) ("[O]nce over that threshold [demonstrating a government interest], the government's choice among the means to accomplish its end is entitled to deference."); Carew-Reid $v$ Metropolitan Transportation Authority, 903 F2d 914, 917-18 (2d Cir 1990) (transportation authority had interest in banning amplified music on subway platforms).

${ }^{13}$ See ISKCON of Potomac, Inc $v$ Kennedy, 61 F3d 949, 956 (DC Cir 1995) (National Park Service ban on solicitation on the National Mall too broad).

14 A clear example is the National Capital Region in Washington, D.C. Permit applications for demonstrations in the Region, which includes the National Mall, have skyrocketed since the early 1990s, from approximately three thousand in 1992 to almost five thousand in 1994. 60 Fed Reg 17639, 17639 (1995) (discussing need for a rule change limiting sales of items like T-shirts in the Region).

${ }^{15}$ See Martin H. Redish, The Content Distinction in First Amendment Analysis, 34 
The D.C. Circuit's approach to Ward, while a significant step towards the creation of such a doctrine, is inadequate alone. This Comment seeks to formulate a clear legal rule that resolves Ward's apparent contradiction and ensures that First Amendment speech rights are considered by government managers of public fora. Section I of this Comment details the history and holding of Ward against the background of the public forum doctrine. Section II then distinguishes the prevailing circuit court approach to Ward from the D.C. Circuit's approach. Section III then augments the D.C. Circuit's approach and concludes that a reviewing court should analyze less-speech-restrictive regulatory alternatives whenever the regulation in question bans a medium of speech.

\section{THE PUBLIC FORUM, WARD V ROCK AGAINST RACISM, AND THE "NARROWLY TAILORED" REQUIREMENT}

\section{A. The Public Forum}

Public parks, streets, and sidewalks are "public fora" for the exercise of First Amendment speech rights. In Hague $v$ CIO, the Supreme Court explained that "[ $t]$ he privilege of a citizen of the United States to use the streets and parks for communication of views . . . must not, in the guise of regulation, be abridged or denied." ${ }^{\text {I6 }}$ Indeed, the Court has historically recognized that speech in parks, and on streets and sidewalks, merits maximum protection. ${ }^{17}$

The Supreme Court, however, has never required government actors to allow unfettered exercise of First Amendment rights in traditional public fora. The Court has explained:

Stan L Rev 113, 128 (1981) ("The most puzzling aspect of the distinction between contentbased and content-neutral restrictions is that either restriction reduces the sum total of information or opinion disseminated."). Professor Stone offers an example of a contentneutral regulation that would effectively destroy speech: "No person may make any speech; distribute any leaflet; publish any newspaper, magazine, or other periodical; operate any radio, television, or cable system; or engage in any other form of public communication." Geoffrey R. Stone, Content-Neutral Restrictions, 54 U Chi L Rev 46, 58 (1987).

307 US 496, 515-16 (1939).

${ }^{17}$ See, for example, id (parks and streets); United States $v$ Grace, 461 US 171, 177 (1983) (sidewalks); Carey v Brown, 447 US 455, 460 (1980) (streets and sidewalks); Cox $v$ New Hampshire, 312 US 569, 574 (1941) (streets).

The public forum doctrine facilitates important values. See Geoffrey $R$. Stone, Fora Americana: Speech in Public Places, 1974 S Ct Rev 233, 238 (Parks and streets, after Hague, are in the "public trust" and set aside, at least in part, for speech.); Harold L. Quadres, Content-Neutral Public Forum Regulations: The Rise of the Aesthetic State Interest, the Fall of Judicial Scrutiny, 37 Hastings L J 439, 486 (1986) (Public fora "preserve a situs for voices otherwise lost in the wilderness."). 
[E]ven in a public forum the government may impose reasonable restrictions on the time, place, or manner of protected speech, provided the restrictions "are justified without reference to the content of the regulated speech, that they are narrowly tailored to serve a significant governmental interest, and that they leave open ample alternative channels for communication of the information." 18

Thus, any government regulation on speech in a public forum must satisfy this "narrowly tailored" requirement.

B. Ward, Clark $v$ Community for Creative Non-Violence, and the "Narrowly Tailored" Requirement

The Supreme Court refined the narrowly tailored requirement most recently in Ward. Ward, however, draws heavily for its rationale on Clark $v$ Community for Creative Non-Violence. ${ }^{19}$

Clark stands for the proposition that if the government can show that its interest in a content-neutral regulation is substantial, then the judiciary should regard the regulation as narrowly tailored. In Clark, the Court considered the constitutionality of a National Park Service ("Park Service") regulation that allowed camping only in certain parks. ${ }^{20}$ The Community for Creative Non-Violence ("CCNV"), as part of an effort to demonstrate the plight of the homeless, sought to camp overnight in Lafayette Park in Washington, D.C. A Park Service regulation, however, prohibited camping at this location. ${ }^{21}$ The Park Service denied CCNV's request, after which CCNV sought an injunction requiring the Park Service to allow the organization's planned activity. The district court granted summary judgment in favor of the Park Service, and the D.C. Circuit, sitting en banc, voted six to five to reverse. ${ }^{22}$ The D.C. Circuit reasoned that the Park Service could have employed less-speech-restrictive means of promoting the park's physical integrity, such as restricting the number of tents or campsites. ${ }^{23}$

\footnotetext{
${ }^{18}$ Ward, 491 US at 791, quoting Clark $v$ Community for Creative Non-Violence, 468 US 288, 293 (1984) (emphasis added).

${ }^{19} 468$ US 288 (1984).

${ }^{20} 36$ CFR § 50.27(a) (1983), in effect at the time of Clark, read: "Camping [in National Parks] is permitted only in areas designated by the Superintendent."

${ }^{21}$ Clark, 468 US at 290.

${ }^{22}$ Community for Creative Non-Violence $v$ Watt, 703 F2d 586, 587 (DC Cir 1983), reversed, 468 US 288 (1984).

${ }^{23} 703$ F2d at 599 .
} 
The Supreme Court granted certiorari and reversed..$^{24}$ Justice White, writing for the majority, began by assuming that sleeping constituted expressive activity protected by the First Amendment. ${ }^{25}$ White then considered whether the regulation was narrowly tailored. Rejecting the circuit court's holding that less restrictive means than a total camping ban existed and would have met the government's interest in maintaining the physical integrity of Lafayette Park, White stated:

There is no gainsaying that preventing overnight sleeping will avoid a measure of actual or threatened damage to Lafayette Park .... [The] suggestions that the Park Service minimize the possible injury by reducing the size, duration, or frequency of demonstrations ... represent no more than a disagreement with the Park Service over how much protection the core parks require or how an acceptable level of preservation is to be attained .... We do not believe that ... the time, place, or manner decisions assign to the judiciary the authority to replace the Park Service as the manager of the Nation's parks .... .

Ward, decided a few years later, seems to place some bounds on the judicial deference afforded government actors in Clark. At the same time, however, Ward clarifies a singularly deferential proposition: that a reviewing court should not evaluate lessspeech-restrictive alternatives in deciding if a content-neutral restriction is narrowly tailored. ${ }^{27}$ The regulation at issue in Ward was intended, in part, to control noise levels in Central Park. ${ }^{28}$ Rock Against Racism argued, among other things, that the city's regulation was not the "Teast intrusive" means of doing so. ${ }^{29}$ The Second Circuit agreed, maintaining that, among other options, the City could simply have directed Rock Against Racism's sound technician to keep concert volume below certain levels. ${ }^{30}$ The Supreme Court disagreed. Justice Kennedy, writing for the majority, explained:

The Court of Appeals erred in sifting through all the available or imagined alternative means of regulating sound vol-

24 Clark, 468 US at 292.

¿ Id at 293:

${ }^{26}$ Id at 299.

Ward, 491 US at 798-99.

${ }^{2 *}$ Id at $785-86$.

${ }^{20}$ Id at 789.

${ }^{30}$ Rock Against Racism v Ward, 848 F2d 367, 371-72 (2d Cir 1988), rev'd, 491 US 781 (1989). 
ume in order to determine whether the city's solution was the "least intrusive means" of achieving the desired end .... Our cases quite clearly hold that restrictions on the time, place, or manner of protected speech are not invalid "simply because there is some imaginable alternative that might be less burdensome on speech." 31

The Ward Court, however, recognized that regulations can occasionally restrict too much speech. Justice Kennedy explained that a content-neutral speech regulation will not be found narrowly tailored if it restricts "substantially more speech than is necessary to further the government's legitimate interests." 32 Thus, under some circumstances, the sheer breadth of a regulation would not permit judicial deference. But:

So long as the means chosen are not substantially broader than necessary to achieve the government's interest, [ ] the regulation will not be invalid simply because a court concludes that the government's interest could be adequately served by some less-speech-restrictive alternative. ${ }^{33}$

Kennedy made no effort, however, to explain the circumstances under which a regulation would be found to restrict "substantially more speech than is necessary."

\section{The Clark and Ward Dissents}

In both Clark and Ward, Justice Marshall wrote vigorous dissents highly critical of the majority's approaches. In Clark, Marshall was particularly bothered by what he saw as a new approach to First Amendment jurisprudence. Marshall reasoned that, after Clark, only content-based speech restrictions would be subject to strict judicial scrutiny. ${ }^{34} \mathrm{He}$ noted, however, that "content-neutral regulations are also capable of unnecessarily restricting protected expressive activity. ${ }^{35}$ Furthermore, Marshall argued, the motives and behavior of government officials who formulate and administer content-neutral restrictions are not above reproach. Marshall spoke of what he regarded as the tendency of government actors to overregulate speech. He believed

${ }^{31}$ Ward, 491 US at 797, quoting United States v Albertini, 472 US 675, 689 (1985).

${ }^{32}$ Ward, 491 US at 799.

${ }^{33}$ Id at 800 . See also Frisby $v$ Schultz, 487 US 474, 485 (1988) ("A complete ban [on a medium of speech] can be narrowly tailored, but only if each activity within the proscription's scope is an appropriately targeted evil.").

${ }^{34}$ Clark, 468 US at 312-13 (Marshall dissenting).

${ }^{35}$ Id at 313. 
that the Park Service's refusal to issue CCNV a camping permit manifested this tendency. ${ }^{36}$

Marshall's primary complaint in Ward was that the majority had taken the already deferential language of Clark too far. Now, the Court had abandoned what Marshall regarded as an essential ingredient of the Court's jurisprudence: the requirement that a speech regulation be the least intrusive restriction necessary to achieve the regulator's goals. ${ }^{37}$ As a consequence of the Ward decision, Marshall noted, "it will be enough [ ] that the challenged regulation advances the government's interest only in the slightest, for any differential burden on speech that results does not enter the calculus." ${ }^{38}$ Marshall also wondered how the Court could possibly evaluate whether a regulation restricted "substantially more speech than is necessary" without also considering the existence of less-speech-restrictive alternatives. ${ }^{39}$

\section{CIRCUIT COURT INTERPRETATIONS OF WARD AND CLARK}

\section{A. The Prevailing View}

Almost all of the circuits have interpreted Ward and Clark in a manner deferential to government actors. In these circuits, if the government can show merely that a regulation of speech is content-neutral and that it advances a significant government interest, then the First Amendment inquiry comes to an end and the regulator prevails. Two cases illustrate this approach. ${ }^{40}$

In Association of Community Organizations for Reform Now $v$ St. Louis County, ${ }^{41}$ ("ACORN") the Court of Appeals for the Eighth Circuit held that an ordinance prohibiting in-the-roadway solicitation of motorists was narrowly tailored. ${ }^{42}$ During the district court proceedings, the Association provided the testimony of an expert who promoted an eight-point plan that, according to the expert, would make on-the-roadway solicitation safe. ${ }^{43}$ The

${ }^{35}$ Id at 314-15.

${ }^{37}$ Ward, 491 US at 804-05 (Marshall dissenting).

ss Id at 806.

${ }^{39}$ Id at 807.

10 The examples here are from the Eighth and Second Circuits. Other circuits have adopted a substantially similar approach. See Messer $v$ City of Douglasville, 975 F2d 1505, 1513 (11th Cir 1992) (municipal sign ordinance as applied to historic district narrowly tailored); Stokes $v$ City of Madison, 930 F2d 1163, 1170-71 (7th Cir 1991) (ordinance restricting use of sound amplification equipment narrowly tailored).

"930 F2d 591 (8th Cir 1991).

${ }^{42}$ St. Louis County Traffic Code $\$ 1209.090$ (1985) provided: "No person shall stand in a roadway for the purpose of soliciting a ride, employment, charitable contribution or business from the occupant of any vehicle." ACORN, $930 \mathrm{~F} 2 \mathrm{~d}$ at 593.

* ACORN, 930 F2d at 594. 
Association contended that because a less-speech-restrictive alternative existed to the complete ban, the county's regulation was not narrowly tailored.44

The court of appeals, affirming the district court, responded that the County, through its own experts and testimony, had substantiated that on-the-roadway solicitation was potentially dangerous and had therefore met Ward's requirement that a content-neutral regulation of First Amendment speech further a significant governmental interest. ${ }^{45}$ This showing was enough for the Eighth Circuit; the court left no room in the ACORN decision for an "alternatives" analysis. ${ }^{46}$

In Carew-Reid $v$ Metropolitan Transportation Authority, ${ }^{47}$ the Court of Appeals for the Second Circuit addressed the constitutionality of a regulation that banned the use of amplifiers on New York City subway platforms. ${ }^{48}$ The New York City Transit Authority ("NYCTA") found that musicians who used amplifiers on subway platforms routinely exceeded eighty-five decibels. According to the NYCTA, amplified music interfered with police communications and the work of track crews. Thus, the NYCTA believed that a ban on amplified music was necessary to ensure public safety. ${ }^{49}$

Carew-Reid, a street musician, disagreed. He maintained that the regulation was "substantially broader than necessary" because there was no necessary connection between amplified music and loud music; musicians could play amplified music at a lower decibel level..$^{50}$ An obvious alternative to the regulation therefore existed: the NYCTA could simply prohibit amplified music from exceeding eighty-five decibels. Thus, Carew-Reid argued, the NYCTA could have enforced this alternative regulation with decibel meters. The district court agreed and determined that the regulation was not narrowly tailored. ${ }^{51}$ The Second Circuit reversed and held that the district court had improperly applied Ward. ${ }^{52}$ Refusing to second-guess the NYCTA, the court

4 Id at $596 \&$ n 3.

4 Id at 596-97; Association of Community Organizations for Reform Now v St. Louis County, 726 F Supp 747, 753 (E D Mo 1989), affd 930 F2d 591 (8th Cir 1991).

${ }^{46}$ ACORN, 930 F2d at 597.

${ }^{43} 903$ F2d 914 (2d Cir 1990).

49 21 NY Comp Codes R \& Regs $\S 1050.6(c)(4)$ (1989) bans entirely the use of amplifiers on subway platforms managed by the New York City Transit Authority. Carew-Reid, 903 F2d at 915-16.

${ }^{4}$ Carew-Reid, 903 F2d at 916.

${ }^{30}$ Id at 917.

${ }^{51}$ Carew-Reid $v$ Metropolitan Transportation Authority, 1990 US Dist LEXIS 64 at *22 (S D NY).

${ }^{52}$ Carew-Reid, 903 F2d at 917-18. 
maintained that "Rock Against Racism makes clear that lessrestrictive alternative analysis has no part in the review of a time, place or manner regulation." ${ }^{\text {33 }}$ The NYCTA had demonstrated its interest in the regulation, and that was enough.

\section{B. The D.C. Circuit's View}

The D.C. Circuit's approach to Ward and Clark contrasts starkly with both ACORN and Carew-Reid. In the early 1990s, the court rejected the highly deferential interpretation of Ward adopted by other circuits. ${ }^{54}$ Instead, the court scrutinizes the government's interest in regulation. According to the D.C. Circuit, when the government lacks an adequate interest in the regulations at issue, the regulations are necessarily too broad. ${ }^{55}$

Henderson $v$ Lujan ${ }^{56}$ concerned the constitutionality of a Park Service regulation that prohibited the distribution of literature in the immediate vicinity of the Vietnam Veterans Memorial. ${ }^{57}$ Henderson had distributed religious leaflets on sidewalks near the Memorial ${ }^{58}$ but the Memorial was not visible from the sidewalks Henderson frequented. ${ }^{59}$ After the Park Service notified Henderson that his actions were illegal, Henderson sued for an injunction to prevent enforcement of the regulation. ${ }^{60}$ The district court enjoined enforcement of the regulation and reasoned that the sidewalks were a public forum and that the Park Service's interest in tranquillity surrounding the Memorial did not justify the regulation. ${ }^{61}$

The D.C. Circuit agreed. ${ }^{62}$ The sidewalks where Henderson distributed his leaflets were adjacent to already busy streets. Thus, the Park Service could not plausibly maintain that its aesthetic interest applied where Henderson had distributed his leaflets. ${ }^{63}$ Nonetheless, the Park Service argued that Ward and Clark required the court to defer to its judgments. ${ }^{64}$ Judge Wil-

\footnotetext{
$s$ Id at 918.

${ }^{*}$ See Henderson $v$ Lujan, 964 F2d 1179 (DC Cir 1992); United States $v$ Doe, 968 F2d 86 (DC Cir 1992).

Henderson, 964 F2d at 1185; Doe, 968 F2d at 91.

is 964 F2d 1179 (DC Cir 1992).

${ }^{57}$ See 36 CFR $\$ 7.96(j)(2)(v i)$ (1991) (prohibiting "[t]he sale or distribution of newspapers, leaflets, and pamphlets" within the area designated by the Park Service as the "Vietnam Veterans Memorial").

${ }^{5}$ Henderson, 964 F2d at 1180 .

${ }^{59}$ Id.

Id at 1181.

${ }^{61}$ Henderson $v$ Lujan, 768 F Supp 1, 3 (D DC 1991), affd, 964 F2d 1179 (DC Cir 1992).

${ }^{i 2}$ Henderson, 964 F2d at 1181.

${ }^{\infty}$ Id at 1184-85.

${ }^{\mathrm{s}} \mathrm{Id}$ at 1185.
} 
liams, writing for the court, responded that the language in Ward requiring that a regulation not be "substantially broader than necessary" was inconsistent with the idea that the government is entitled to entirely deferential review. ${ }^{65}$ Thus, according to Judge Williams, the government was required to establish its interest in regulating public forum speech in the exact location where Henderson desired to exercise his First Amendment rights. Judge Williams then found that the Park Service failed to demonstrate such an interest in preventing Henderson from distributing his leaflets. ${ }^{66}$

In United States $v$ Doe, the D.C. Circuit again determined that the government lacked a substantial interest in a speech regulation. ${ }^{67}$ Doe challenged the constitutionality of a regulation that limited musical instruments to a noise level of sixty decibels in national parks. ${ }^{68}$ As part of a protest against the Gulf War, Doe played a drum in Washington's Lafayette Park. ${ }^{69}$ The Park Service arrested Doe and charged her with a violation of the noise regulation. Doe moved to dismiss the charges and alleged that the regulation was an unconstitutional violation of her First Amendment rights. ${ }^{70}$ The district court rejected her argument and held that the regulation was a reasonable time, place, and manner restriction, that the government had an interest in maintaining tranquillity in park spaces, and that the noise restriction furthered that interest. ${ }^{71}$

The D.C. Circuit disagreed. ${ }^{72}$ The court reasoned that the Park Service did not have the same kind of interest in regulating noise levels at Lafayette Park that it had, for example, at Okefenokee National Wildlife Refuge-a more serene venue. ${ }^{73}$ The court accepted Doe's argument that Lafayette Park is simply a noisy place, and then concluded that the Park Service had not demonstrated its interest in limiting noise to sixty decibels. ${ }^{74}$

Doe demonstrates that the D.C. Circuit regards its review of regulations differently than do both the ACORN and Carew-Reid courts: "This court has characterized 'the test of "narrow tailor-

\footnotetext{
is Id.

${ }^{66}$ Id.

" 968 F2d 86, 89 (DC Cir 1992).

* 36 CFR § 2.12(a)(1)(i) (1991) prohibited "[o]perating ... an audio device, such as a . .. musical instrument, in a manner ... [t] that exceeds a noise level of 60 decibels measured on the A-weighted scale at 50 feet."

${ }^{69}$ Doe, 968 F2d at 87.

${ }^{70}$ Id.

"I Id.

${ }^{72}$ Id.

${ }^{73}$ Id at 90 .

${ }^{7}$ Id at $90-91$.
} 
ing" ... as a balancing test, inquiring whether the restriction "burdens more speech than is necessary to further the government's legitimate interests."'m75 Indeed, to speak of Ward as requiring a "balancing" of the burdened speech with the government's interest is unique. ${ }^{76}$ Other circuits are not interested in such balancing; rather, the majority view among the circuits seems to be that the only relevant interest is the government's interest. ${ }^{77}$

The D.C. Circuit further demonstrated its unique approach to Clark and Ward in ISKCON of Potomac, Inc $v$ Kennedy ("ISKCON"). ${ }^{78}$ Here, for the first time since Ward, a circuit court embraced an analysis of less-speech-restrictive alternatives in ruling on the constitutionality of a content-neutral regulation. Yet it did so not in contravention of Ward, but in a way that made sense of Ward's injunction that a regulation not restrict "more speech than is necessary."

The International Society for Krishna Consciousness ("Society") wanted, among other things, to solicit contributions from passersby on the National Mall. Although the collection of alms is an established part of Hare Krishna practice, ${ }^{79}$ the Society's permit to conduct a "Krishnafest" on the Mall was revoked for failing to comply with a federal regulation. ${ }^{80}$ After the Park Service and Department of Interior refused to permit the festival, the Society brought an action for declaratory relief. ${ }^{81}$ The district court held that the solicitation regulation, as applied to the National Mall, unconstitutionally infringed on the Society members' First Amendment speech rights. ${ }^{82}$

The D.C. Circuit agreed. ${ }^{83}$ According to the court, the regulation, as applied to the National Mall, was not narrowly tailored

${ }^{75}$ Id at 88, quoting Henderson, 964 F2d at 1184, quoting Ward, 491 US at 799.

${ }^{76}$ Many scholars have expressed their concern that "balancing" is underprotective of speech. "Balancers" can give disproportionate weight to government interests. See, for example, T. Alexander Aleinikoff, Constitutional Law in the Age of Balancing, 96 Yale L J 943, 1002-04 (1987) (noting the existence of desirable alternatives to balancing). Nevertheless, balancing in the content-neutral speech regulation context is a stricter form of review than the deferential form represented, for example, by the ACORN and CarewReid courts.

" See, for example, ACORN, $930 \mathrm{~F} 2 \mathrm{~d}$ at 596.

${ }^{2 *} 61$ F3d 949 (DC Cir 1995).

$\because$ Id at 953.

\& 36 CFR $\$ 7.96$ (h) (1994) prohibited "soliciting or demanding gifts, money, goods or services" at any park, including the National Mall, in the National Capital Region.

"ISKCON, 61 F3d at 953.

${ }^{82}$ Id; ISKCON of Potomac, Inc $v$ Ridenour, 830 F Supp 1, 4 (D DC 1993).

$\approx$ ISKCON, 61 F3d at 959 (The D.C. Circuit agreed that the prohibition on seeking voluntary contributions was unconstitutional, but the court held that the prohibition on sales of tapes and beads was permissible.). 
because it burdened "substantially more speech than is necessary." ${ }^{\text {"I }}$ In the court's view, individuals or groups participating in authorized demonstrations or special events could solicit donations within the confines of a restricted permit area without preventing others from enjoying the Mall. Thus, the court concluded that, rather than banning solicitation entirely, the Park Service could have limited solicitation to certain locations on the Mall or regulated solicitation methods and practices. ${ }^{85}$

ISKCON became the first post-Ward public forum decision explicitly to embrace less-speech-restrictive alternatives analysis as a way of making sense of the Ward Court's mandate that a regulation not restrict "substantially more speech than is necessary." The D.C. Circuit's apparent resurrection of less-speechrestrictive alternatives analysis is not, however, surprising. Courts simply cannot determine whether a regulation restricts "more speech than is necessary"86 without inquiring into the existence of less-speech-restrictive alternatives.

\section{CONSTRUCTING A NEW APPROACH TO THE NARROWLY- TAILORED REQUIREMENT}

\section{A. A Heightened Standard of Review}

Courts should evaluate the existence of less-speechrestrictive alternatives when they find that a regulation bans an entire medium of speech in a public forum. ${ }^{87}$ This would constitute an intermediate standard of review-between the strict

${ }^{84}$ Id at 956.

${ }^{25}$ Id.

${ }^{66}$ Ward, 491 US at 799 (emphasis added).

${ }^{n}$ This proposal is hereinafter described as the "heightened standard." A judicial analysis of less-speech-restrictive alternatives to content-neutral public forum regulations is only one possible way to strengthen the narrowly-tailored requirement. A reviewing court could alternatively make the government firmly establish its interest in a regulation, perhaps through strengthened evidentiary requirements. See David Goldberger, Judicial Scrutiny in Public Forum Cases: Misplaced Trust in the Judgment of Public Officials, 32 Buff L Rev 175, 220 (1983) ("The obvious remedy is to increase scrutiny in a fashion that more carefully links specific factual considerations to judicial decision making.").

Also, a court could attempt to circumscribe the domain of valid governmental interests. Minimizing pedestrian traffic congestion may, for example, be a legitimate government interest, but the promotion of park aesthetics may not be. In reviewing contentneutral regulations, however, the Supreme Court has tended to regard almost all interests claimed by the government as legitimate. See, for example, Members of City Council of Los Angeles $v$ Taxpayers for Vincent, 466 US 789, 807 (1984) (recognizing the sufficiency of the city's claimed aesthetic interest for First Amendment purposes).

Neither of these approaches, however, would get directly at the hard question posed by Ward: Under what circumstances does a regulation restrict "substantially more speech than is necessary"? 491 US at 779 (emphasis added). 
scrutiny applied generally to content-based regulations, ${ }^{88}$ and the reasonability standard applied to content-neutral regulations of nonpublic fora. ${ }^{89}$ This heightened standard would, most importantly, clarify Ward: it would provide a functional understanding of when a regulation restricts "substantially more speech than is necessary."

While the D.C. Circuit's post-Ward jurisprudence provides a useful starting point for developing a heightened standard of review, Henderson, Doe, and ISKCON do not provide a coherent account of when a court should analyze less-speech-restrictive alternatives. These decisions establish that (1) the interests of the speaker are relevant to the question of whether a content-neutral speech regulation is narrowly tailored (Doe and Henderson) ${ }^{91}$ and (2) a court must occasionally analyze less-speech-restrictive alternatives to a content-neutral speech regulation to determine whether a regulation restricts "substantially more speech than is necessary" (ISKCON). ${ }^{92}$ The former provides the justification for a heightened standard. The latter is of limited usefulness, however, until an effort is made to suggest when a regulation might restrict "substantially more speech than is necessary."

Thus, this Comment proposes that a reviewing court should fear that a regulation restricts "substantially more speech than is necessary" whenever the regulation bans an entire "medium of speech." Here, "speech" refers merely to any expression protected by the First Amendment. ${ }^{94} \mathrm{~A}$ "medium" of speech is any vehicle for engaging in protected speech. Examples include leafleting, public speaking, and other communicative activities, including the wearing of message-bearing T-shirts ${ }^{95}$ and solicitation. ${ }^{96}$

* See note 7.

s9 See, for example, Adderley $v$ Florida, 385 US 39, 47 (1966) (no First Amendment right to demonstrate on jailhouse grounds); United States $v$ Kokinda, 497 US 720, 727 (1990) (regulation of speech-related activity on post office grounds subject only to reasonability review).

Ward, 491 US at 799.

st See notes 75-77 and accompanying text.

$\$$ See notes 78-86 and accompanying text.

$\$ 3$ Again, Ward is of no help here. See text accompanying notes 37-39.

See, for example, text accompanying note 25 .

ss The sale of message-bearing T-shirts is a more difficult issue. For conflicting examples of how courts have dealt with this issue, see Friends of Vietnam Veterans Memorial $v$ Kennedy, 899 F Supp 680, 688 (D DC 1995) (Park Service ban on the sale of messagebearing T-shirts on the National Mall unconstitutional); One World One Family Now $v$ City and County of Honolulu, 76 F3d 1009, 1016 (9th Cir 1996) (ordinance banning the sale of message-bearing $\mathrm{T}$-shirts in public forum constitutional).

The Supreme Court has emphasized solicitation's important First Amendment status. See Village of Schaumburg v Citizens for a Better Environment, 444 US 620 (1980) (declaring unconstitutional a municipal ordinance restricting charitable solicitation). 
A regulation "bans" a medium of speech when it does not allow, under any circumstances, the use of the medium anywhere within a given forum or "management unit."197 Consider, for example, leafleting as a medium of speech and a park as the public forum. The government could allow leafleting in a park without any restrictions. Alternatively, it could restrict leafleting by limiting the time of day, location in the park, or conditions under which leafleting would be permitted (by requiring a permit, for example). ${ }^{98}$ Or the government could ban all leafleting throughout the park.

The concept of a "management unit" is necessary in order to distinguish between a permissible "restriction" of speech and an outright "ban." If a regulation limits leafleting to certain predetermined areas within a park, for example, then the regulation could be said to "restrict" that medium of speech in the park or "management unit." If the regulation prohibits that medium of speech throughout an entire park or "management unit," that regulation "bans" that medium of speech. ${ }^{99}$

The ease with which a court could apply this heightened standard would vary with the type of public forum involved. A problem-free application is a public park: the boundaries of a park are usually easy to identify. Sidewalks and streets are more problematic. What is, for example, a "management unit" of a sidewalk? It is difficult to divide a city's sidewalks into a sensible set of "units"; sidewalks are often continuous throughout a city. A possible solution does exist, however. Courts can determine whether some regulated sidewalks constitute a "management unit" by referring to the buildings surrounded by the sidewalks: ${ }^{100}$ In United States $v$ Grace, ${ }^{101}$ for example, the Supreme Court decided that the public forum regulated in that controversy was the group of sidewalks surrounding the Court's building. ${ }^{102}$ The government urged the Court to construe the public forum as a much larger set of sidewalks. If the government had

\footnotetext{
${ }^{97}$ Courts are familiar with the need to identify the scope of a public forum. See, for example, United States $v$ Grace, 461 US 171, 180 (1983) (Public sidewalks surrounding the Supreme Court building and grounds are a public forum.).

${ }^{95}$ The regulation in Henderson, for example, restricted where on the National Mall individuals could distribute leaflets. See note 57 and accompanying text.

${ }^{99}$ The regulation in ISKCON, for example, banned solicitation throughout the $\mathrm{Na}$ tional Mall. See note 80 and accompanying text.

${ }^{100} \mathrm{~A}$ court could similarly identify a "management unit" of streets.

${ }^{100} 461$ US 171 (1983).

${ }^{102}$ Id at 180.
} 
prevailed, it could have claimed that sufficient alternatives for expression existed in the larger forum. ${ }^{103}$

B. The Government's Tendency to Overregulate and the Potential Problem of Improper Motivation

This heightened standard of review would effectively deal with the two concerns Marshall expressed in his dissent in Clark: the government's tendency to overregulate speech in public fora and the possibility of improper government motivation in the formulation of speech regulations. ${ }^{104}$ Each problem is difficult to detect, but both are of real concern. ${ }^{105}$

1. The tendency to overregulate.

This tendency to overregulate stems from the dynamics of interest group influence on government actors. "Quiet" users of parks are more numerous and influential than those who seek to use parks for expressive purposes. While visiting a park, these "quiet" users prefer not to be interrupted by demonstrators or others exercising their First Amendment speech rights. ${ }^{106}$ Public forum speakers are frequently poor, often minorities, and tend to have little organized political influence. ${ }^{107}$ As such, government actors may disregard the desires of such speakers. Government actors often react to this "influence imbalance," predictably, by banning certain speech media. ${ }^{108}$

The heightened standard is one way of dealing with the tendency of government actors to overregulate speech. ${ }^{109}$ If a ban were subject to a judicial analysis of less-speech-restrictive

Id at 180-81.

"Clark, 468 US at 314-15 (Marshall dissenting). See text accompanying notes 34-36.

"Nee, for example, Stone, $54 \mathrm{U}$ Chi L Rev at 56 (cited in note 15) ("The problem, of course, is that the government rarely admits that it is attempting to restrict a particular message because it disagrees with the ideas expressed .... [T]he government usually claims that legitimate governmental interests support the restriction.").

${ }^{\text {tw5 }}$ Goldberger, 32 Buff L Rev at 208 (cited in note 87).

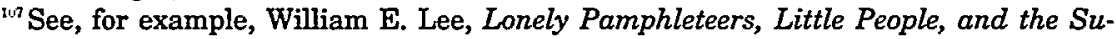
preme Court: The Doctrine of Time, Place, and Manner Regulations of Expression, 54 Geo Wash L Rev 757, 765 (1986) ("Inexpensive media-such as leaflets, parades, street demonstrations, and picketing-are simply more important to poorly financed communicators than to the wealthy."); Harry Kalven, Jr., The Negro and the First Amendment 210 (Chicago 1966) ("We would do well to avoid the occasion for any new epigrams about the majestic equality of the law prohibiting the rich man, too, from distributing leaflets or picketing."); Kenneth L. Karst, Equality as a Central Principle in the First Amendment, $43 \mathrm{U}$ Chi L Rev 20, 36 (1975) ("[E]ven a content-neutral time, place, and manner restriction may have unequal effects on various types of messages.").

${ }^{\text {tux }}$ See Clark, 468 US at 315-16 (Marshall dissenting) (Park Service's decision to enforce the camping ban at Lafayette Park likely a result of interest group pressure).

See note 87 . 
regulatory alternatives, the government actor would, at a minimum, have to explain why the ban was uniquely necessary to further its interest. ${ }^{110}$ Without this heightened standard of review, the government actor would merely fulfill the wishes of the "quiet" park-user constituency, while offering a reviewing court a plausible justification for the regulation. ${ }^{111}$

In addition, a reviewing court should be most suspicious that the government has "cut a constituency deal" when the government actor has taken the "easy approach" to solving its perceived public forum problem: a ban on an entire troublesome medium of speech. Corrective measures short of complete bans often exist. ${ }^{112}$ In ISKCON, for example, the D.C. Circuit could not understand why the Park Service did not simply restrict solicitation to less troublesome parts of the National Mall; in the court's view, the Park Service did not need to ban all solicitation. ${ }^{113}$

\section{Improper motivation.}

Improper'motives are often associated with government actors that promulgate content-based speech regulations. ${ }^{114} \mathrm{Im}-$ proper motives, however, are also a problem in the contentneutral speech regulation context. ${ }^{115}$ Constitutional scholars have noted this possibility. ${ }^{116}$ Since government actors are usually

\footnotetext{
${ }^{10}$ The exact deterrent effect on government actors provided by the judicial analysis of less-speech-restrictive alternatives would depend on the rigor of such analysis. For a brief discussion, see Section III.E. Even if a reviewing court only analyzed obvious alternatives (the least rigorous form of less-speech-restrictive alternatives analysis), such an approach would likely minimize the government's tendency to overregulate. Under those conditions, a government actor would at least have to offer a compelling explanation for its rejection of the obvious alternatives.

${ }^{\text {"II }}$ Goldberger, 32 Buff $\mathrm{L}$ Rev at 208 (cited in note 87).

${ }^{112}$ In Carew-Reid, for example, the NYCTA could have used decibel meters to enforce a noise restriction on amplifiers. See text accompanying notes 47-53. In Clark, the Park Service used a permit system to regulate camping rather than prohibit it outright. See 468 US at 310-11 (Marshall dissenting). See text accompanying notes 19-26. The judiciary does not need to be particularly clever to recognize obvious alternatives.

${ }^{113}$ ISKCON, 61 F3d at 956.

"is "Improper motives" here refers to a government effort to restrict speech on the basis of its content. Content-based restrictions are generally repugnant to the First Amendment. See note 7 .

${ }^{115}$ See Clark, 468 US at 315-16 (Marshall dissenting) (viewpoint neutrality not a "shield" against the regulation of unpopular ideas).

${ }^{116}$ See, for example, Elena Kagan, Private Speech, Public Purpose: The Role of Governmental Motive in First Amendment Doctrine, $63 \mathrm{U}$ Chi L Rev 413 (1996). Kagan argues that the Supreme Court's First Amendment jurisprudence can be described generally as "motive-hunting." Id at 414. Content-neutral laws can pose the danger of "improper purpose." Id at 456. The Supreme Court, argues Kagan, has recognized the spectre of improper motivation for content-neutral regulations in three particular instances: laws conferring "standardless" discretion, laws turning on the "communicative effect" of speech, and laws attempting to "equalize" the "speech market." Id.
} 
committed to the "interest of the general public," they are often "disproportionately sensitiv[e]" to the disruption that certain messages can cause among other users of public fora. ${ }^{177}$

This "oversensitivity" need not result in content-based speech restrictions. There are, after all, many ways to regulate an unpopular speaker. The government actor can simply ban the particular medium the speaker tends to employ. A government actor responding to a locale's distaste for Jehovah's Witnesses, for example, could ban the distribution of leaflets generally (rather than distribution of its magazine, Watchtower). Such a regulation would, on its face, be content-neutral. ${ }^{118}$

More searching judicial review of bans on media of speech would minimize the potential influence of improper motives on government actors. If a government actor knows that a court will subject its regulation to less-speech-restrictive alternatives analysis, it will probably select regulatory measures that allow media employed by unpopular groups or individuals to enjoy continued use in the forum, if only on a more limited scale. ${ }^{119}$

\section{Prior Supreme Court Decisions}

1. Decisions consistent with the heightened standard.

This heightened standard of review is not particularly novel. Older Supreme Court decisions concerning content-neutral regulations of public fora support a bright-line rule with regard to bans on entire media of speech. ${ }^{120}$ The first of these, Schneider $v$ State, ${ }^{121}$ explicitly cited the existence of less-speech-restrictive alternatives as a reason for declaring a content-neutral speech regulation unconstitutional. ${ }^{122}$ Schneider reviewed a number of ordinances banning the distribution of handbills in public fora. ${ }^{123}$

\footnotetext{
${ }^{17}$ Clark, 468 US at 314-16 (Marshall dissenting).

${ }^{11 \times}$ See Goldberger, 32 Buff $L$ Rev at 207 (cited in note 87) (noting that government actors can promulgate content-neutral restrictions in response to "controversial" speech).

"'A judicial review of less-speech-restrictive alternatives should at least induce government actors to consider alternatives. The Supreme Court, for example, has long explained that permit ordinances will not be upheld if they grant the government actor too much discretion in accepting or rejecting the permit application. See, for example, Lovell $v$ City of Griffin, 303 US 444, 451 (1938). The result has been permit schemes which identify the exact procedures by which applications will be handled. See Freedman $v$ Maryland, 380 US 51, 58 (1965) (systems constitutional only if accompanied by adequate safeguards "to obviate the dangers of a censorship system").

${ }^{12}$ At the time of these decisions, the Court did not yet write in the language of "content-neutral" and "public forum."

${ }^{122} 308$ US 147 (1939).

${ }^{122}$ Id at 162 .

${ }^{123}$ One of these, $\S 28.01$ of the Municipal Code of the City of Los Angeles, stated: "No person shall distribute any hand-bill to or among pedestrians along or upon any street,
} 
The Supreme Court, concluding that less-speech-restrictive measures would have allowed the cities to satisfy their interest in litter reduction, observed that "[t]here are obvious methods of preventing littering. Amongst these is the punishment of those who actually throw papers on the streets." ${ }^{124}$

Similarly, in Martin $v$ City of Struthers,${ }^{125}$ the Court held that an ordinance restricting the distribution of leaflets in residential areas was unconstitutional. ${ }^{126}$ The Court explained that "[f]reedom to distribute information to every citizen . . . is so clearly vital to the preservation of a free society that . . . it must be fully preserved." "127 The city could have dealt with the "dangers of [leaflet] distribution" by "traditional legal methods," such as general trespass statutes. ${ }^{128}$

Schneider and Martin have never been explicitly overruled, and have continued to influence the Court. ${ }^{129}$ Each case stands for the proposition that the judiciary should review contentneutral regulations to make sure that they are not too draconian. ${ }^{130}$ Moreover, the Supreme Court has identified the existence of less-speech-restrictive alternatives wher evaluating contentbased regulations of speech. ${ }^{131}$ The heightened standard of review proposed by this Comment would simply require such analysis when courts review the "medium-banning" class of contentneutral speech regulations.

sidewalk, or park." Schneider, 308 US at 154.

${ }^{12}$ Id at 162.

${ }^{125} 319$ US 141 (1943).

${ }^{126}$ Id at 149. The Struthers ordinance read, in relevant part: "It is unlawful for any person distributing handbills ... to ring the door bell, sound the door knocker, or otherwise summon the inmate or inmates of any residence to the door for the purpose of receiving such handbills." Id at 142.

${ }^{127}$ Id at $146-47$.

${ }^{122}$ Id at 147.

${ }^{22}$ See, for example, City of Ladue v Gilleo, $114 \mathrm{~S} \mathrm{Ct} 2038,2045$ (1994) (city ordinance banning all signs on residences violates homeowners' free speech rights); Forsyth County $v$ Nationalist Movement, 505 US 123, 134 (1992) (ordinance assessing fee for cleaning up demonstrators' leaflets not content-neutral).

${ }^{130}$ Schneider continues to be invoked by circuit courts as well. See, for example, Hays County Guardian v Supple, 969 F2d 111, 119 (5th Cir 1992) (prohibition of newspaper distribution unconstitutional where narrowed prohibition or regulation would vindicate the regulator's interests).

${ }^{131}$ See Lamont $v$ Postmaster General, 381 US 301, 310 (1965) (Brennan concurring) (Government must "confine itself to the least intrusive regulations which are adequate for the purpose."); Shelton $v$ Tucker, 364 US 479, 488 (1960) ("The breadth of legislative abridgment must be viewed in the light of less drastic means for achieving the same basic purpose."); Cantwell v Connecticut, 310 US 296, 304 (1940) (Exercise of regulatory power must not unduly infringe upon protected freedoms.). 
2. Possible objections.

The heightened standard is consistent with Clark, though this is not apparent at first glance. Clark was seemingly a case in which a regulation banned a medium of speech (camping). ${ }^{132}$ Nevertheless, the Clark Court refused to consider less-speechrestrictive alternatives to the ban. ${ }^{133}$

In Clark, however, the Supreme Court did not seriously consider whether camping was a medium of speech and, instead, merely assumed that it was. ${ }^{134}$ Indeed, in his dissent, Justice Marshall argued that a full consideration of camping's expressive aspects was necessary in order to evaluate the sufficiency of the government's interests in regulating the conduct. ${ }^{135}$ Thus, the heightened standard would only be applied after the reviewing court first determined that the "medium ban" actually restricted protected speech.

Another objection also requires a response. The Ward Court explained that it was not the role of the judiciary to "manage" public fora. ${ }^{136}$ Less-speech-restrictive alternatives analysis, however, need not involve the judiciary in public forum "management." Whether judicial scrutiny under the heightened standard amounted to "management" would depend on how rigorously courts analyzed alternative means of regulation. ${ }^{137} \mathrm{~A}$ court's finding that obvious alternatives to a content-neutral speech regulation existed would hardly constitute "management." Under this form of alternatives analysis, a government actor need only give a compelling explanation for banning a medium of speech.

The "judicial management" objection seems misguided in another way. All judicial restrictions on how government actors manage public fora can be thought of as "judicial management." The judiciary monitors public fora, for example, to ensure that forum speech regulations are content-neutral. ${ }^{138}$ Yet few complain that this kind of judicial scrutiny constitutes unwarranted "judicial management." It is "management" nonetheless. Public

${ }^{132}$ See text accompanying notes $20-21$.

${ }^{133} 468$ US at 299.

${ }^{13 x}$ Id at 293.

${ }^{135}$ Marshall explained: "The majority's approach [assuming that camping is protected speech] denatures respondent's asserted right and thus makes all too easy identification of a Government interest sufficient to warrant its abridgment." Id at 302 (Marshall dissenting).

${ }^{136}$ Ward, 491 US at 798, quoting Clark, 468 US at 299.

${ }^{137}$ For a brief discussion of the possible forms of less-speech-restrictive alternatives analysis, see Section III.D.

${ }^{25}$ See note 7 . 
forum "management," after all, is simply about dictating what can and cannot be done in parks, on sidewalks, and on streets.

The "management objection," at best, is a veiled reference to a comparative expertise argument. The argument is that the judiciary is ill-suited to make the kinds of factual determinations necessary to assess how public fora should be operated; therefore, the judiciary should not analyze alternatives to a government actor's selected regulation. Even a strong version of this argument, however, does not necessarily foreclose all judicial alternatives analysis. Only "overreaching" alternatives analysis, such as a mandatory experimentation period, would be inappropriate.

\section{Alternative Standards of Review}

Courts could evaluate the existence of less-speech-restrictive regulatory alternatives in at least three other ways. The first approach would be for a court to apply heightened scrutiny (including an analysis of less-speech-restrictive alternatives) in reviewing all content-neutral public forum regulations. This seems to be how Justice Marshall viewed the law as it existed before Ward. ${ }^{139}$ This approach would be more protective of speech than this Comment's proposal. However, it is not the law, and its implementation would require overturning Ward. A judicial analysis considering less-speech-restrictive alternatives only when a regulation bans a medium of speech would reconcile different aspects of Ward, without overturning it.

Second, reviewing courts could adopt a narrow reading of Schneider and Martin and apply a less-restrictive-alternatives analysis only when a regulation bans certain "traditional" speech media (such as leafleting). Reviewing courts, however, should regard Schneider's and Martin's focus on leafleting as incidental. New speech media are unquestionably entitled to First Amendment protection. ${ }^{140}$

A'third approach is more compelling but nevertheless troubling. Under this approach, a court would engage in less-speechrestrictive alternatives analysis only when the regulation in question banned all (or at least many) speech media in a public forum. Post-Ward circuit courts, even outside the D.C. Circuit, have declared content-neutral speech regulations unconstitu-

\footnotetext{
${ }^{159}$ Ward, 491 US at 804 (Marshall dissenting) ("Our cases have not, as the majority asserts, 'clearly' rejected a less-restrictive-alternative test."), quoting id at 797 (majority opinion).

${ }^{140}$ See, for example, Turner Broadcasting System, Inc v FCC, 114 S Ct 2445, 2456 (1994) (Cable television communications receive full First Amendment protection.), citing Leathers $v$ Medlock, 499 US 439, 444 (1991).
} 
tional when this is the case. ${ }^{141}$ The argument for this approach is simple: when a regulation bans enough media in a forum, the capacity of speakers to engage in protected expression is severely limited because few alternative media may remain. When a regulation only bans one medium (such as solicitation), however, speakers can still utilize others (leafleting, for example). ${ }^{142}$

This third approach is inadequate. Speakers have good reasons for selecting their media. The law should respect such choices. Otherwise, speakers seeking to exercise their rights in public fora could be relegated to using inferior media or to not communicating their views at all. Hare Krishnas solicit contributions because solicitation forms a vital part of their religious expression. ${ }^{143}$ The CCNV wanted to sleep at Lafayette Park, rather than simply carry banners or distribute leaflets, in protest of homelessness, because sleeping in the park was the best way to express its message. ${ }^{144}$ Also, certain media of speech are uniquely suited to underfinanced groups or individuals. ${ }^{145}$

Moreover, a reviewing court would have great difficulty knowing whether truly viable alternatives would exist in the context of the regulation. A regulation could ban comparatively modern media (playing amplified music or wearing messagebearing T-shirts), but not impinge upon others (leafleting and solicitation). Would such a regulation be restrictive enough to trigger the judicial analysis of less-speech-restrictive alternatives? Probably not. In practice, reviewing less-speech-restrictive alternatives when enough media are banned would likely be indistinguishable from reviewing alternatives only when regulations ban traditional media. ${ }^{146}$ The problems with the traditionalversus-modern distinction, discussed above, would resurface.

\footnotetext{
"These courts did not, however, employ less-speech-restrictive alternatives analysis in making this determination. See, for example, Jews for Jesus, Inc v Massachusetts Bay Transportation Authority, 984 F2d 1319, 1328 (1st Cir 1993) (declaring unconstitutional an ordinance that banned virtually all expression on certain subway platforms).

${ }^{142}$ In Clark, for example, the Court noted that although CCNV members could not sleep overnight at Lafayette Park, the group was free to hold "day-and-night" vigils and otherwise demonstrate. 468 US at 295. See text accompanying notes 19-26.

${ }^{14}$ ISKCON, 61 F3d at 953.

${ }^{14}$ Clark, 468 US at 306 (Marshall dissenting) ("[B]y using sleep as an integral part of [their] mode of protest, [CCNV members] 'can express with their bodies the poignancy of their plight."), quoting CCNV $v$ Watt, 703 F2d at 601 (Edwards concurring).

${ }^{1 *}$ See note 107.

${ }^{245}$ In Jews for Jesus, for example, the court identified the regulation's ban on leafleting and solicitation of signatures, both "traditional" media of speech, as particularly troubling. 984 F2d at 1324-25.
} 
E. The Substance of Less-Speech-Restrictive Alternatives Analysis

The controversy over Ward's meaning today has not concerned how courts should analyze less-speech-restrictive regulatory alternatives. It has concerned, rather, whether courts should even consider that such alternatives exist. Nevertheless, a brief discussion of how courts apply less-speech-restrictive alternatives analysis is appropriate.

In applying the analysis, courts need to resolve two issues: the extent to which government actors must explore regulatory alternatives, and the extent to which alternatives must achieve success similar to the proposed regulation's in meeting the government's interest. Each issue has many possible resolutions. The courts could require government actors to experiment with alternatives or could merely require that government actors clearly explain their failure to adopt an alternative. Concerning the second issue, courts could consider only alternatives that substantially achieve the government's interest, or could consider even those alternatives that only partly advance the government's interest.

The Supreme Court has never made an effort to answer these questions, but it has implied that reviewing courts should at least consider obvious alternatives that advance the government's interests, even if those alternatives do so less effectively. ${ }^{147}$ In ISKCON, the D.C. Circuit adopted a similar approach. An obvious alternative to the solicitation ban was for the Park Service to allow solicitation at a limited number of sites on the Mall. ${ }^{148}$ Under this approach, if a court finds that obvious, less-speech-restrictive alternatives to a regulation exist and that the government has not adequately explained the necessity of a ban, then the court determines that the regulation is not narrowly tailored. ${ }^{149}$ But even if reviewing courts only held government actors accountable for obvious alternatives, this would be a dramatic improvement on the current law of most federal circuits. A judicial evaluation of obvious alternatives would provide at least a modicum of additional protection to the speech rights of those who wish to use public fora to express their views.

\footnotetext{
${ }^{147}$ The alternatives mentioned in both Schneider and Martin certainly qualify as "obvious" alternatives. See text accompanying notes 121-28.

${ }^{14}$ ISKCON, 61 F3d at 956.

${ }^{149}$ Id at 955-56.
} 


\section{CONCLUSION}

Ward $v$ Rock Against Racism raised the question of whether reviewing courts are ever authorized to evaluate the existence of less-speech-restrictive alternatives to content-neutral speech regulations. In the years following Ward, most federal circuits have answered the question in the negative. This approach to Ward has undermined the speech rights of those who wish to use public fora. The D.C. Circuit's jurisprudence, however, suggests that Ward requires reviewing courts to evaluate the existence of less-speech-restrictive alternatives when the regulation in question restricts "substantially more speech than is necessary." The risk of overregulation is highest when the regulation bans a medium of speech. To minimize this risk, reviewing courts should assess the existence of less-speech-restrictive alternatives when the regulation in question bans an entire medium of speech. 
